\title{
Africa Business Research as a Laboratory for Theory-Building: Extreme Conditions, New Phenomena, and Alternative Paradigms of Social Relationships
}

\author{
Helena Barnard, ${ }^{1}$ Alvaro Guervo-Gazurra, ${ }^{2}$ \\ and Stephan Manning ${ }^{3}$ \\ ${ }^{1}$ University of Pretoria, South Africa, ${ }^{2}$ Northeastern University, USA, and ${ }^{3}$ University of \\ Massachusetts at Boston, USA
}

ABSTRACT Africa is an increasingly important business context, yet we still know little about it. We review the challenges and opportunities that firms in Africa face and propose that these can serve as the basis for extending current theories and models of the firm. We do so by challenging some of the implicit assumptions and stereotypes on firms in Africa and by proposing three avenues for extending theories. One is taking the extreme conditions of some Africa countries and using them as a laboratory for modifying current theories and models of the firm, as we illustrate in the case of institutional theory and the resource-based view. A second one is identifying new themes that arise from analyzing firms in Africa and their contexts of operation, and we discuss four themes: migrating multinationals and the meaning of home country, diaspora networks within and across countries, a recasting of cultural and institutional distance, and new hybrid organizational forms. A third one is developing new theories based on alternative paradigms of social relationships that have emerged in Africa that differ from those underpinning existing theories of the firm, such as kgotla and its view of community-based relationships or ubuntu and its humanizing view of relationships.

KEYwORDs Africa, context, emerging markets, international business, theory development

\section{INTRODUGTION}

Firms in Africa have received little attention in the mainstream management literature. There are very few articles analyzing business and management in Africa in top academic journals (for some recent reviews see George, Corbishley, Khayesi, Haas, \& Tihanyi, 2016; Kolk \& Rivera-Santos, 2016). The paucity of research can be ascribed to the dual effect of limited support and lack of incentives for publishing in top journals for academics at Africa's universities, as well as the limited availability of reliable secondary datasets capturing the empirical realities of the African context. Thus, local researchers who have a deep contextual 
understanding of the conditions under which firms in Africa operate have little incentive to do academic research, and often receive limited research training (Nkomo, 2015). At the same time, scholars from elsewhere who are potentially interested in researching firms in Africa find it hard to collect data and understand the particular conditions of firms operating there. As a result, most of the research done on African firms remains anecdotal and has not led to substantial novel theoretical contributions; instead, most studies have been an application of existing theories and insights from management and international business research to the African context (George et al., 2016).

More rigorous and comprehensive research on Africa is needed to truly benefit scholarship on business and management in the African context and beyond. In doing so, researchers need to free their minds from preconceptions of typical risks and opportunities. In fact, empirical evidence of business activity in Africa, which we also report in this editorial, contradicts the usual perception of Africa as a too-risky business context. At the same time, it nonetheless suggests the importance of being realistic about economic prosperity in Africa. More importantly, we invite readers to think differently about where business opportunities in Africa come from and how to conceptualize risks in a context like Africa. There are different dimensions of the business world at play in Africa that we are only beginning to understand.

Based on that notion, we suggest that it is worth questioning established theories and current conceptions of management research in their applications to the context of Africa, because researchers thus far have rarely comprehended the actual situation in Africa. By researching business in Africa we are trying to understand some limitations of existing theories and models, and stress the importance of developing new knowledge. An example may be useful: Around 2000, Mandla Adonisi, a scholar at the Gordon Institute of Business Science at the University of Pretoria in South Africa, used well-established North American scales for corporate entrepreneurship in a comparative study of firms in South Africa and Nigeria. The scale functioned adequately in South Africa, but not at all in Nigeria. At the time, there was very little appetite for management research coming from Africa, and he decided to focus his work on South Africa rather than investigate the puzzling discrepancy between the South African and Nigerian evidence. Unfortunately, what he had uncovered - that a hitherto well-established scale of corporate entrepreneurship was ill-suited to capture actual practices of entrepreneurship in some countries in Africa although not in others - was a potentially useful contribution to the field at large that remained undisclosed.

In this article, we thus propose and explain three approaches by which the study of business and management in Africa can not only help extend existing theories of the firm but also serve as the basis for new theories and perspectives. Figure 1 summarizes the ideas we discuss: extreme conditions, new phenomena, and alternative paradigms of social relationships.

The first approach, extreme conditions, is using the sometimes-severe circumstances of some African countries as a laboratory for modifying and 


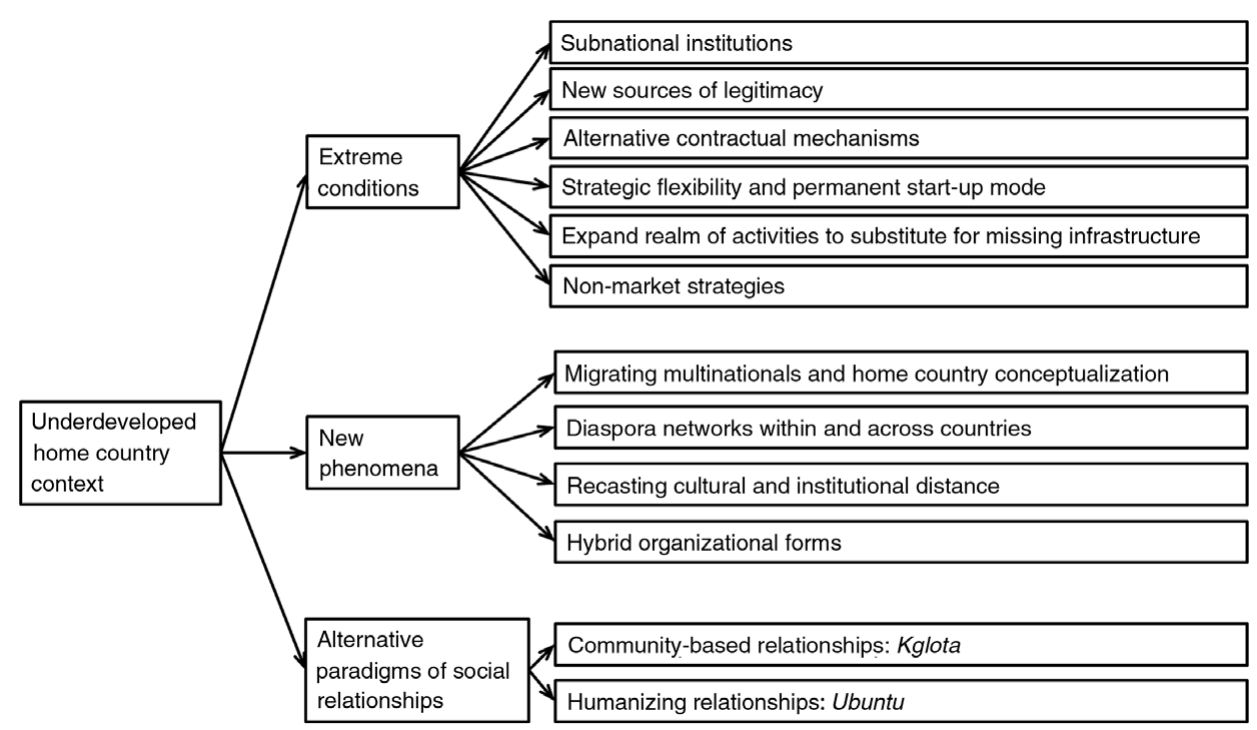

Figure 1. Main concepts and ideas discussed in the article

extending current theories and models of organizations and international business. Take, for example, firms operating in Zimbabwe during the hyperinflation period. Despite massive outmigration during the economic crisis, the science-based Zimbabwean firm SeedCo remained in Zimbabwe and is now the leading seed company on the continent, spending more than seven percent of revenue on R\&D (SeedCo, 2016). In addition to accelerated market-seeking internationalization, young Zimbabwean firms emerged as 'migrating multinationals' (Barnard, 2014) as operational and financial headquarters were moved to more stable neighbors. Understanding how those firms navigated a very turbulent environment can shed light on fundamentals in management, and we illustrate this by explaining some of the implications for institutional theory and the resource-based view.

A second approach, new phenomena, is identifying specific trends and themes that are unique to or particularly important in the African context and that exemplify the complex conditions that firms in Africa face and the strategic responses they apply. For example, the Democratic Republic of Congo has vast mineral wealth, a population of 73 million, and the $11^{\text {th }}$ largest land mass on earth. Yet, it has less than 2800 kilometers (1700 miles) of paved roads, and road conditions are harrowing (Willems, 2010). Logistics presents a particular challenge, and some firms manage logistics in this profoundly underdeveloped context through technologically sophisticated planning and radio-frequency identification (RFID) systems. The spectrum of strategies and practices used by firms present a number of intriguing managerial and theoretical questions that open the venue for new themes and topics. We discuss four of them: migrating multinationals and home country conceptualization, diaspora networks within and across countries, recasting cultural and institutional distance, and new hybrid organizational forms. 
The third approach, alternative paradigms of social relationships, is developing new theoretical perspectives based on particular philosophies and views of social relationships that prevail in some parts of Africa and that differ from those underpinning current theories that were developed in advanced economies. We suggest that scholarship in Africa may give rise to more community-centered theories of business conduct. In particular, ubuntu, the African concept that 'I only exist through my interaction with you', has started to receive attention in management studies (Mangaliso, 2001). Similarly, the kgotla practice of collaborative leadership is increasingly being recognized (Beugre, 2016). We realize that theorizing how different views of human relations shape management is hard; scholarship builds on previous work and therefore scholars need to find ways to frame their work within a dominant set of 'representations and counter-representations' (Nkomo, 2011). However, this is a particularly exciting avenue for further work, as it can serve not just to extend existing theories but as the basis for building new theories.

The rest of the paper is organized as follows. In the next section, we provide an overview of African countries and the main companies in Africa to provide some empirical background for those who know little about the region. It may also help dispel some of the preconceptions and misunderstandings about the region and its companies. We then discuss how we can use some of the extreme conditions that companies in some African countries face as the basis for extending existing theories. After this, we explain new phenomena and trends that are emerging in Africa and new strategies that African companies are taking that can be the basis for new research topics. We then explain how we can use some of the distinct philosophical traditions of some African countries to try to create new theories that reflect a different view of social relationships.

\section{AFRIGA AS A RESEARGH SETTING}

Africa is a rapidly changing continent and business context. There has been a swift urbanization and transformation of economic relationships in recent years, as individuals have moved from traditional and rural relationships to modern relationships in urban settings using new technologies (Henderson, Storeygard, \& Roberts, 2013; Little, 2013; Turok \& McGranahan, 2013). Combined with a third albeit uneven 'wave' of democratization (Crawford \& Lynch, 2013), this has increased business opportunities across the continent. However, Africa is not homogenous. Because borders among countries were decided by colonial powers rather than reflecting the reality of individuals living there, there is not only a very large diversity across the 54 countries that compose Africa, but there is also 'ethnolinguistic fractionalization' (Luiz, 2015) within those countries. This challenges the usual association of national borders with distinct economic realities. Figure 1 illustrates this ethnolinguistic diversity and how it matches little with current country boundaries, in marked contrast with other regions of the world where national borders tend to match a language. 


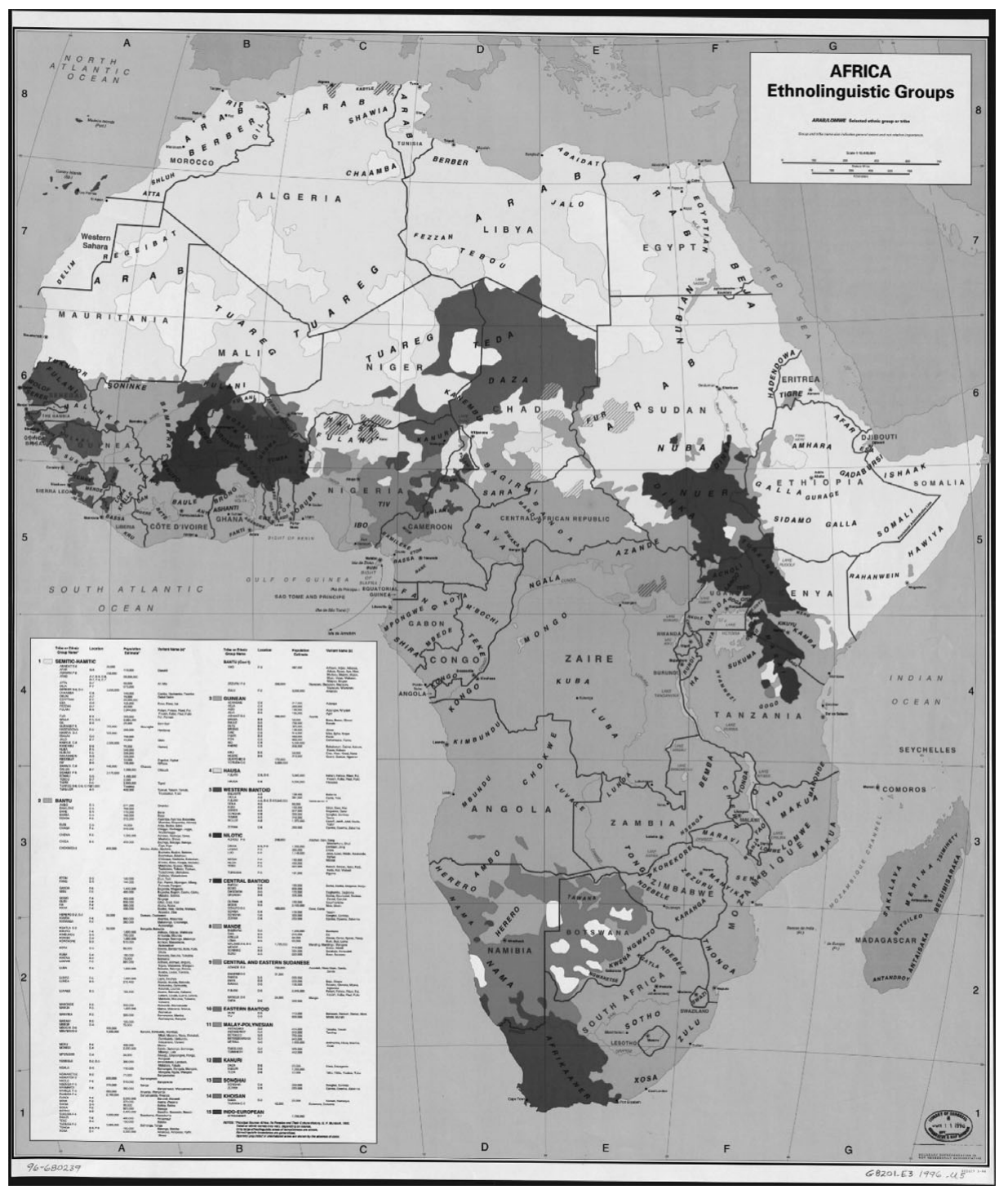

Figure 2. Ethnolinguistic map of Africa

Source: United States. Central Intelligence Agency. Library of Congress Geography and Map Division, Call number G8201.E3 1996. U5 This map is available from the United States Library of Congress's Geography \& Map Division under the digital ID g8201e.ct001294. https://en.wikipedia. org/wiki/List_of_regions_of_Africa\#/media/File:Africa_ethnic_groups_1996.jpg

One useful way to make sense of the diversity of the continent is to divide Africa into five regions: Northern Africa (Algeria, Egypt, Libya, Morocco, Sudan, Tunisia, Western Sahara); Western Africa (Benin, Burkina Faso, Cape Verde, Ivory Coast, Gambia, Ghana, Guinea, Guinea-Bissau, Liberia, Mali, Mauritania, Niger, Nigeria, Saint Helena, Senegal, Sierra Leone, Togo); Central Africa (Angola, Cameroon, Central African Republic, Chad, Democratic Republic of the Congo, Republic of the Congo, Equatorial Guinea, Gabon, Sño Tomé and 
Príncipe); Eastern Africa (Burundi, Comoros, Djibouti, Eritrea, Ethiopia, Kenya, Madagascar, Malawi, Mauritius, Mayotte, Mozambique, Reunion, Rwanda, Seychelles, Somalia, Tanzania, Uganda, Zambia, Zimbabwe); and Southern Africa (Botswana, Lesotho, Namibia, South Africa, Swaziland). North Africa, which includes for example Morocco, Tunisia, and Egypt, is often considered separately from sub-Saharan Africa, given that North Africa shares some cultural similarities with what is considered the Middle East and that the Saharan desert acts as a natural barrier to the rest of Africa. Within sub-Saharan Africa, one can separate Western, Eastern, Central, and Southern Africa. Western Africa includes, for example, Senegal, Ghana, and Nigeria; Central Africa includes Sudan, Cameroon, and Congo; Eastern Africa includes Ethiopia, Kenya, and Tanzania; Southern Africa includes South Africa, Namibia, and Botswana. These are geographic regions rather than cultural or political groupings, even though some countries within each of the regions share commonalities in ethnic groups and colonial pasts. Indeed, scholars have found that the quality of regional institutions affects firm-level innovation (Barasa, Knoben, Vermeulen, Kimuyu, \& Kinyanjui, 2017). Moreover, in a context with substantial infrastructural weakness, geographic proximity matters. Trade blocks also more or less follow the divide, although they tend to spill over to adjacent countries and it is not rare for a country to be a member of more than one block. Thus, we have the East African Community, Southern African Development Community, the Customs and Economic Union of Central Africa, and the Economic Community of West African States that aim to facilitate economic relationships among countries.

Table 1 provides some statistics to illustrate the large diversity of conditions of these countries. Regarding landmass, Africa is the second-largest continent on the planet, almost $70 \%$ the size of Asia. The population of Africa is virtually double that of Latin America, and comparable to that of India and China. However, Africa is very fragmented; more than $60 \%$ of the population lives in just ten of the 54 African countries, while only four countries (Algeria, South Africa, Egypt, and Nigeria) constitute almost 60\% of the Gross Domestic Product (GDP) of Africa. Although the average GDP per capita in Africa is still very low, and 37 countries have in fact a GDP per capita below the African mean, there is an increasing number of countries that can be described as 'lower-middle' or even 'upper-middle' income countries.

South Africa is an anomaly. It is the fifth most populous country in Africa, and the ninth biggest country in terms of land mass. Regarding total GDP, it ranks third (behind the more populous Egypt and Nigeria), and in terms of GDP per capita, it ranks eighth, reflecting the continued inequalities in the country postApartheid. The country overwhelmingly dominates in terms of formal economic activity. Consider for example the Forbes Global 2000 (Table 2), which ranks publicly traded companies by a basis of a mix of sales, profits, assets, and market value. Thirteen of the 21 African firms on the list are from South Africa, followed by Nigeria with four, Morocco with three and Egypt with one. 
Table 1. Basic indicators of countries in Africa

\begin{tabular}{|c|c|c|c|c|c|c|}
\hline & $\begin{array}{l}\text { Population } \\
\text { (thousands) }\end{array}$ & $\begin{array}{l}\text { Land } \\
\text { area } \\
\text { (thousands } \\
\text { of km2) }\end{array}$ & $\begin{array}{c}\text { Population } \\
\text { density } \\
\text { (pop. I } \\
\text { km2) }\end{array}$ & $\begin{array}{c}\text { GDP based } \\
\text { on PPP } \\
\text { valuation } \\
\text { (USD Million) }\end{array}$ & $\begin{array}{c}\text { GDP per } \\
\text { Capita (PPP } \\
\text { valuation, } \\
\text { USD) }\end{array}$ & $\begin{array}{l}\text { Annual real } \\
\text { GDP growth } \\
\text { (average over } \\
\text { 2007-2015) }\end{array}$ \\
\hline Algeria & 39667 & 2382 & 17 & 570638 & 14386 & 3.1 \\
\hline Angola & 25022 & 1247 & 20 & 185246 & 7403 & 6.2 \\
\hline Benin & 10880 & 115 & 95 & 21156 & 1945 & 4.5 \\
\hline Botswana & 2262 & 582 & 4 & 37160 & 16424 & 4.7 \\
\hline Burkina Faso & 18106 & 274 & 66 & 31184 & 1722 & 5.9 \\
\hline Burundi & 11179 & 28 & 402 & 7882 & 705 & 3.4 \\
\hline Cabo Verde & 521 & 4 & 129 & 3479 & 6684 & 3 \\
\hline Cameroon & 23344 & 475 & 49 & 72109 & 3089 & 4.1 \\
\hline $\begin{array}{l}\text { Central African } \\
\text { Republic }\end{array}$ & 4900 & 623 & 8 & 3052 & 623 & -1.4 \\
\hline Chad & 14037 & 1284 & 11 & 32003 & 2280 & 5 \\
\hline Comoros & 788 & 2 & 424 & 1214 & 1539 & 1.7 \\
\hline Congo & 4620 & 342 & 14 & 28919 & 6259 & 4.4 \\
\hline $\begin{array}{l}\text { Congo, Dem. } \\
\text { Rep. }\end{array}$ & 77267 & 2345 & 33 & 63266 & 819 & 6.9 \\
\hline Côte d'Ivoire & 22702 & 322 & 70 & 78335 & 3451 & 4.6 \\
\hline Djibouti & 888 & 23 & 38 & 3093 & 3484 & 5.2 \\
\hline Egypt* & 91508 & 1001 & 91 & 995969 & 10884 & 4.1 \\
\hline $\begin{array}{c}\text { Equatorial } \\
\text { Guinea }\end{array}$ & 845 & 28 & 30 & 25944 & 30701 & 6.8 \\
\hline Eritrea & 5228 & 118 & 44 & 7939 & 1519 & 1.9 \\
\hline Ethiopia* & 99391 & 1104 & 90 & 159224 & 1602 & 10.5 \\
\hline Gabon & 1725 & 268 & 6 & 34409 & 19944 & 4.5 \\
\hline Gambia & 1991 & 11 & 176 & 3269 & 1642 & 3.7 \\
\hline Ghana & 27410 & 239 & 115 & 113349 & 4135 & 6.7 \\
\hline Guinea & 12609 & 246 & 51 & 15276 & 1212 & 2.2 \\
\hline Guinea-Bissau & 1844 & 36 & 51 & 2676 & 1451 & 3.3 \\
\hline Kenya & 46050 & 580 & 79 & 143051 & 3106 & 5.1 \\
\hline Lesotho & 2135 & 30 & 70 & 5777 & 2706 & 4.7 \\
\hline Liberia & 4503 & 111 & 40 & 3781 & 840 & 6.3 \\
\hline Libya & 6278 & 1760 & 4 & 92875 & 14793 & 0.2 \\
\hline Madagascar & 24235 & 587 & 41 & 35556 & 1467 & 2.6 \\
\hline Malawi & 17215 & 118 & 145 & 20558 & 1194 & 5.6 \\
\hline Mali & 17600 & 1240 & 14 & 29151 & 1656 & 3.9 \\
\hline Mauritania & 4068 & 1031 & 4 & 16427 & 4039 & 3.7 \\
\hline Mauritius & 1273 & 2 & 624 & 24509 & 19250 & 4 \\
\hline Morocco & 34378 & 447 & 77 & 274526 & 7986 & 4.1 \\
\hline Mozambique & 27978 & 799 & 35 & 33726 & 1205 & 7 \\
\hline Namibia & 2459 & 824 & 3 & 24839 & 10102 & 4.6 \\
\hline Niger & 19899 & 1267 & 16 & 18960 & 953 & 5.6 \\
\hline Nigeria & 182202 & 924 & 197 & 1105343 & 6067 & 6 \\
\hline Rwanda & 11610 & 26 & 441 & 20321 & 1750 & 7.5 \\
\hline $\begin{array}{l}\text { Sao Tome and } \\
\text { Principe }\end{array}$ & 190 & 1 & 198 & 664 & 3488 & 4.8 \\
\hline Senegal & 15129 & 197 & 77 & 36300 & 2399 & 3.8 \\
\hline Seychelles & 96 & 0.46 & 210 & 2533 & 26259 & 4.7 \\
\hline Sierra Leone & 6453 & 72 & 90 & 9832 & 1524 & 5.1 \\
\hline Somalia & 10787 & 638 & 17 & $\ldots$ & $\ldots$ & $\ldots$ \\
\hline South Africa & 54490 & 1219 & 45 & 724010 & 13287 & 2.3 \\
\hline
\end{tabular}


Table 1. Continued.

\begin{tabular}{|c|c|c|c|c|c|c|}
\hline & $\begin{array}{l}\text { Population } \\
\text { (thousands) }\end{array}$ & $\begin{array}{l}\text { Land } \\
\text { area } \\
\text { (thousands } \\
\text { of km2) }\end{array}$ & $\begin{array}{c}\text { Population } \\
\text { density } \\
\text { (pop. / } \\
\text { km2) }\end{array}$ & $\begin{array}{c}\text { GDP based } \\
\text { on PPP } \\
\text { valuation } \\
\text { (USD Million) }\end{array}$ & $\begin{array}{c}\text { GDP per } \\
\text { Capita (PPP } \\
\text { valuation, } \\
\text { USD) }\end{array}$ & $\begin{array}{l}\text { Annual real } \\
\text { GDP growth } \\
\text { (average over } \\
\text { 2007-2015) }\end{array}$ \\
\hline South Sudan & 12340 & 644 & 19 & 22461 & 1820 & 9 \\
\hline Sudan & 40235 & 1879 & 21 & 167421 & 4161 & 4 \\
\hline Swaziland & 1287 & 17 & 74 & 10869 & 8446 & 1.9 \\
\hline Tanzania & 53470 & 947 & 56 & 138304 & 2587 & 6.7 \\
\hline Togo & 7305 & 57 & 129 & 10816 & 1481 & 4.1 \\
\hline Tunisia & 11254 & 164 & 69 & 127213 & 11304 & 2.7 \\
\hline Uganda & 39032 & 242 & 162 & 79753 & 2043 & 6.5 \\
\hline Zambia & 16212 & 753 & 22 & 64647 & 3988 & 7 \\
\hline Zimbabwe & 15603 & 391 & 40 & 27916 & 1789 & 3.1 \\
\hline Africa & 1184501 & 30066 & 39 & 5768932 & 4870 & 4.6 \\
\hline
\end{tabular}

Note: * For Egypt and Ethiopia, fiscal year July (n-1)/June (n).

Sources: United Nations, Department of Economic and Social Affairs, Population Division, World Population Prospects, The 2015 Revision. AfDB Statistics Department, various domestic authorities and AfDB estimates. ADBG (2015).

Table 2. Largest African firms in Forbes 500 (2016)

\begin{tabular}{|c|c|c|c|c|c|c|}
\hline $\begin{array}{l}\text { Rank } \\
2016\end{array}$ & Company & Country & Sales & Profits & Assets & $\begin{array}{c}\text { Market } \\
\text { Value }\end{array}$ \\
\hline 317 & Standard Bank Group & South Africa & 15.40 & 1.90 & 127.70 & 14.40 \\
\hline 440 & Steinhoff International & South Africa & 13.30 & 1.40 & 25.10 & 22.80 \\
\hline 463 & Sasol & South Africa & 13.30 & 1.40 & 24.40 & 20.90 \\
\hline 502 & FirstRand & South Africa & 5.80 & 1.70 & 73.50 & 18.50 \\
\hline 523 & MTN Group & South Africa & 11.50 & 1.60 & 20.30 & 18.90 \\
\hline 680 & Naspers & South Africa & 6.40 & 1.10 & 13.30 & 60.00 \\
\hline 725 & Sanlam & South Africa & 6.60 & 0.74 & 43.20 & 10.50 \\
\hline 1062 & Bidvest Group & South Africa & 15.10 & 0.48 & 6.60 & 8.40 \\
\hline 1148 & Attijariwafa Bank & Morocco & 3.20 & 0.46 & 41.50 & 7.20 \\
\hline 1220 & Dangote Cement & Nigeria & 2.50 & 0.93 & 5.60 & 13.80 \\
\hline 1367 & Commercial International Bank & Egypt & 2.30 & 0.61 & 22.90 & 5.50 \\
\hline 1497 & Shoprite Holdings & South Africa & 9.30 & 0.34 & 3.30 & 6.70 \\
\hline 1529 & Remgro & South Africa & 2.10 & 0.61 & 6.30 & 9.30 \\
\hline 1550 & Zenith Bank & Nigeria & 2.10 & 0.53 & 20.10 & 1.90 \\
\hline 1590 & Aspen Pharmacare Holdings & South Africa & 2.80 & 0.47 & 6.80 & 10.10 \\
\hline 1652 & MMI Holdings & South Africa & 5.30 & 0.24 & 29.00 & 2.60 \\
\hline 1683 & FBN Holdings & Nigeria & 2.80 & 0.40 & 21.60 & 0.60 \\
\hline 1817 & Guaranty Trust Bank & Nigeria & 1.50 & 0.49 & 13.30 & 2.30 \\
\hline 1844 & Banque Centrale Populaire & Morocco & 2.10 & 0.26 & 33.20 & 4.10 \\
\hline 1897 & RMB Holdings & South Africa & 0.32 & 0.61 & 2.50 & 5.80 \\
\hline 1980 & BMCE Bank & Morocco & 1.80 & 0.20 & 28.20 & 3.80 \\
\hline
\end{tabular}

Source: Forbes (2016)

Table 3 lists the largest firms in Africa presented by the periodical Africa Report, which compiles the largest 500 firms using a questionnaire, ranking firms by turnover. Although the largest two firms are the state-owned oil firms from Algeria and Angola, the list is again dominated by South Africa with 160 firms Morocco 
Table 3. Largest firms in Africa (Africa Report)

\begin{tabular}{|c|c|c|c|c|c|c|}
\hline $\begin{array}{l}\text { Rank } \\
2014\end{array}$ & Company & Sector & Country & $\begin{array}{c}\text { Turnover } \\
\text { (2013), } \\
\$ m n\end{array}$ & $\begin{array}{c}\text { Net Profits } \\
(2013), \\
\$ m n\end{array}$ & $\begin{array}{c}\text { Profit/ } \\
\text { turnover \% }\end{array}$ \\
\hline 1 & Sonatrach & Petroleum & Algeria & 67827.8 & 5236.1 & 7.7 \\
\hline 2 & Sonangol & Petroleum & Angola & 40070.0 & 3089.8 & 7.7 \\
\hline 3 & Sasol & Chemicals & South Africa & 17256.8 & 2587.7 & 15.0 \\
\hline 4 & The Bidvest Group & Diversified & South Africa & 14604.1 & 481.0 & 3.3 \\
\hline 5 & Eskom & Utilities & South Africa & 13281.0 & 674.9 & 5.1 \\
\hline 6 & MTN Group & $\begin{array}{l}\text { ICT/ } \\
\text { Telecoms }\end{array}$ & South Africa & 12994.3 & 2894.1 & 22.3 \\
\hline 7 & $\begin{array}{l}\text { Steinhoff } \\
\text { International } \\
\text { Holdings }\end{array}$ & $\begin{array}{l}\text { Wood and } \\
\text { paper }\end{array}$ & South Africa & 10994.3 & 755.9 & 6.9 \\
\hline 8 & Sanlam & Insurance & South Africa & 9710.4 & 869.6 & 9.0 \\
\hline 9 & Shoprite Holdings & Retail & South Africa & 8829.5 & 344.2 & 3.9 \\
\hline 10 & Imperial Holdings & Transport & South Africa & 8794.8 & 350.9 & 4.0 \\
\hline 11 & Bidvest Foods & Agribusiness & South Africa & 7873.0 & 238.0 & 3.0 \\
\hline 12 & Vodacom Group & $\begin{array}{l}\text { ICT/ } \\
\text { Telecoms }\end{array}$ & South Africa & 7207.7 & 1301.1 & 18.1 \\
\hline 13 & Massmart Holdings & Retail & South Africa & 6903.2 & 127.8 & 1.9 \\
\hline 14 & $\begin{array}{l}\text { The Bidvest Group } \\
\text { South Africa }\end{array}$ & Diversified & South Africa & 6597.4 & 399.8 & 6.1 \\
\hline 15 & $\begin{array}{l}\text { Société Nationale } \\
\text { D’Investissement }\end{array}$ & Diversified & Morocco & 6321.4 & n.a. & n.a. \\
\hline 16 & Barloworld & Diversified & South Africa & 6197.7 & 153.7 & 2.5 \\
\hline 17 & $\begin{array}{l}\text { De Beers } \\
\text { Consolidated } \\
\text { Mines }\end{array}$ & Mining & South Africa & 6074.0 & n.a. & n.a. \\
\hline 18 & $\begin{array}{l}\text { Pick'N Pay Stores } \\
\text { Holdings }\end{array}$ & Retail & South Africa & 6060.6 & 55.4 & 0.9 \\
\hline 19 & Naspers & Media & South Africa & 5971.7 & 621.6 & 10.4 \\
\hline 20 & $\begin{array}{l}\text { Société Anonyme } \\
\text { Marocaine De } \\
\text { L'Industrie Du } \\
\text { Raffinage }\end{array}$ & Refining & Morocco & 5943.2 & 38.7 & 0.7 \\
\hline 21 & Sappi & $\begin{array}{l}\text { Wood and } \\
\text { paper }\end{array}$ & South Africa & 5925.0 & -161.0 & -2.7 \\
\hline 22 & $\begin{array}{l}\text { Vodacom South } \\
\text { Africa }\end{array}$ & $\begin{array}{l}\text { ICT/ } \\
\text { Telecoms }\end{array}$ & South Africa & 5883.9 & 1737.0 & 29.5 \\
\hline 23 & Datatec & Media & South Africa & 5688.1 & 55.8 & 1.0 \\
\hline 24 & $\begin{array}{l}\text { Office Chérifien Des } \\
\text { Phosphates }\end{array}$ & Mining & Morocco & 5676.2 & 1043.8 & 18.4 \\
\hline 25 & Anglogold Ashanti & Mining & South Africa & 5497.0 & -2230.0 & -40.6 \\
\hline 26 & Transnet & Transport & South Africa & 5388.9 & 492.3 & 9.1 \\
\hline 27 & $\begin{array}{l}\text { Suez Canal } \\
\text { Authority }\end{array}$ & Ports & Egypt & 5300.0 & n.a. & n.a. \\
\hline 28 & Kumba Iron Ore & Mining & South Africa & 5184.7 & 1932.6 & 37.3 \\
\hline 29 & Aveng & Diversified & South Africa & 5041.7 & -36.3 & -0.7 \\
\hline 30 & $\begin{array}{l}\text { Anglo American } \\
\text { Platinum Corp. }\end{array}$ & Mining & South Africa & 4988.9 & -130.4 & -2.6 \\
\hline 31 & $\begin{array}{l}\text { SABMiller South } \\
\text { Africa }\end{array}$ & $\begin{array}{l}\text { Food and } \\
\text { drink }\end{array}$ & South Africa & 4951.0 & n.a. & n.a. \\
\hline
\end{tabular}


Table 3. Continued

\begin{tabular}{|c|c|c|c|c|c|c|}
\hline $\begin{array}{l}\text { Rank } \\
2014\end{array}$ & Company & Sector & Country & $\begin{array}{c}\text { Turnover } \\
\text { (2013), } \\
\$ m n\end{array}$ & $\begin{array}{c}\text { Net Profits } \\
(2013) \text {, } \\
\$ m n\end{array}$ & $\begin{array}{c}\text { Profit/ } \\
\text { turnover } \%\end{array}$ \\
\hline 32 & MTN Nigeria & $\begin{array}{l}\text { ICT/ } \\
\text { Telecoms }\end{array}$ & Nigeria & 4584.7 & n.a. & n.a. \\
\hline 33 & Spar Group & Retail & South Africa & 4550.2 & 113.3 & 2.5 \\
\hline 34 & Total South Africa & $\begin{array}{r}\text { Petroleum } \\
\text { Services }\end{array}$ & South Africa & 3930.5 & 72.7 & 1.8 \\
\hline 35 & $\begin{array}{l}\text { Entreprise Nationale } \\
\text { De Distribution Et } \\
\text { De Commerciali- } \\
\text { sation Des } \\
\text { Produits Pétroliers }\end{array}$ & $\begin{array}{r}\text { Petroleum } \\
\text { Services }\end{array}$ & Algeria & 3848.0 & n.a. & n.a. \\
\hline 36 & MTN South Africa & $\begin{array}{l}\text { ICT/ } \\
\text { Telecoms }\end{array}$ & South Africa & 3780.1 & n.a. & n.a. \\
\hline 37 & $\begin{array}{l}\text { Middle East Oil } \\
\text { Refineries }\end{array}$ & $\begin{array}{r}\text { Petroleum } \\
\text { Services }\end{array}$ & Egypt & 3571.0 & 94.0 & 2.6 \\
\hline 38 & $\begin{array}{l}\text { Groupe Maroc } \\
\text { Télécom }\end{array}$ & $\begin{array}{l}\text { ICT/ } \\
\text { Telecoms }\end{array}$ & Morocco & 3453.9 & 670.0 & 19.4 \\
\hline 39 & $\begin{array}{l}\text { Global Telecom } \\
\text { Holding } \\
\text { (Ex-Orascom } \\
\text { Telecom) }\end{array}$ & $\begin{array}{l}\text { ICT/ } \\
\text { Telecoms }\end{array}$ & Egypt & 3447.0 & -2914.0 & -84.5 \\
\hline 40 & Liberty Group & Insurance & South Africa & 3406.4 & 425.5 & 12.5 \\
\hline 41 & $\begin{array}{c}\text { Woolworths } \\
\text { Holdings }\end{array}$ & Retail & South Africa & 3370.0 & 251.1 & 7.5 \\
\hline 42 & $\begin{array}{l}\text { Old Mutual Life } \\
\text { Assurance Co. }\end{array}$ & Insurance & South Africa & 3293.3 & 437.2 & 13.3 \\
\hline 43 & $\begin{array}{l}\text { Transnet Freight } \\
\text { Rail }\end{array}$ & $\begin{array}{l}\text { Rail } \\
\text { Transport }\end{array}$ & South Africa & 3275.9 & 346.6 & 10.6 \\
\hline 44 & Cévital & Agribusiness & Algeria & 3260.4 & 381.9 & 11.7 \\
\hline 45 & $\begin{array}{l}\text { Murray \& Roberts } \\
\text { Holdings }\end{array}$ & Construction & South Africa & 3256.7 & 140.0 & 4.3 \\
\hline 46 & $\begin{array}{l}\text { Société Ivoirienne } \\
\text { De Raffinage }\end{array}$ & Refining & Côte d'Ivoire & 3233.2 & 0.3 & 0.0 \\
\hline 47 & $\begin{array}{l}\text { South African } \\
\text { Airways }\end{array}$ & Air Transport & South Africa & 3192.7 & -137.6 & -4.3 \\
\hline 48 & Telkom & $\begin{array}{l}\text { ICT/ } \\
\text { Telecoms }\end{array}$ & South Africa & 3147.4 & 375.4 & 11.9 \\
\hline 49 & $\begin{array}{l}\text { Arcelor Mittal South } \\
\text { Africa }\end{array}$ & Metals & South Africa & 3086.5 & -204.4 & -6.6 \\
\hline 50 & JD Group & Retail & South Africa & 3066.4 & 163.2 & 5.3 \\
\hline
\end{tabular}

Source: Africa Report (2015)

follows with 77, Egypt with 42, Ivory Coast with 28, Nigeria with 25, Algeria with 24, Tunisia with 17, Mauritius with 15, Ghana with 13, Gabon and Kenya with 9, Cameroon, Senegal, and Zimbabwe with 8, Burkina Faso and Zambia with 7, Tanzania with 6, Botswana and Mali with 5, Angola, Democratic Republic of Congo, Mauritania, and Namibia with 3, Malawi, Mozambique, Niger, Sudan, and Uganda with 2, and Congo, Ethiopia, and Swaziland with 1. There are 
significant differences in size, with Sonatrach with US\$67.7bn in sales, followed by Sonangol with US $\$ 40.0 \mathrm{bn}$, Sasol with US $\$ 17.2$, and then quickly dropping in size.

It is noteworthy that some of the iconic South African firms such as the miners Anglo-American and BHP Billiton, the brewer SABMiller (acquired by the Brazilian-Belgian group AB InBev in 2016), and the finance firm Old Mutual, have long not had a primary listing on the South African stock exchange. They have 'migrated' to more developed countries (Barnard, 2014).

\section{EXTENDING THEORY BY ANALYZING EXTREME GONDITIONS}

A first way of leveraging the African context for business research is by assessing the validity and range of established theories against the realities of conducting business under the extreme conditions present in many African countries. By looking at how business is conducted under absent or rapidly changing institutions and infrastructure, it becomes possible to identify and question implicit assumptions of the theories that were typically developed and applied in more developed economic contexts.

Companies in Africa tend to face a combination of relatively unstable political conditions, corrupt and weak governments, limited effectiveness of contract law and property rights, economic disparities, and slow or inconsistent economic growth patterns. Whereas especially the lack of Western-style formal institutions and infrastructures have been considered typical for many emerging economies (Hoskisson, Eden, Lau, \& Wright, 2000; Khanna \& Palepu, 2000; Xu \& Meyer, 2012), the continuously high level of political, institutional and economic uncertainty specifically applies to many African countries (George et al., 2016). In this context, firms face three interrelated conditions that may necessitate a critical review of the applicability of established theories: (1) turbulence through constant change and uncertainty as typical conditions under which firms operate and make investments, (2) local communities retaining a strong role as social infrastructures (both as enabler and constraint of business) because governments and formal institutions are either missing or unstable, and finally, partly the outcome of the other two, (3) the fact that investing into scale and continuous growth is much less of an option for many firms in Africa.

We now further specify implications of these observations for two major theories of organization and strategy: institutional theory and the resource-based view. The former has been used to specify central dimensions of the context within which firms operate and how this context can enable and constrain firm behavior and decision-making (North, 1990). The latter, by comparison, focuses on why firms are different within the same context, based on unique resources and capabilities they develop over time (Penrose, 1959). These theoretical angles are complementary perspectives on firm strategy, not least in international contexts, combining a macro view (institutional theory) with a firm-level perspective (resource-based view) 
(Peng, Sun, Pinkham, \& Chen, 2009). They have merit in guiding research in Africa as well, yet we suggest that they need to be extended to fully accommodate the specificity and complexity of the very conditions firms operate under in African countries.

\section{Extreme Conditions and Institutional Theory}

Institutional theory has been a central pillar in conducting business research in emerging economies (e.g., Hoskisson et al., 2000; Khanna, Krishna, \& Bullock, 2010). Institutions are typically regarded as rather enduring, more or less formal, rules, norms, and frameworks enabling and constraining social interactions in general and business conduct specifically (North, 1990). Although sharing the same name, there are two distinct strands of institutional theory, one from economics and another from sociology. In economics, institutions, such as laws, regulations and norms, are regarded as means of reducing uncertainty, information and transaction costs (North, 1990). In sociology, institutions are seen more broadly as structural enablers and constraints operating at multiple levels - transnational, national, industry/field, local - that either put pressure on firms to comply and adopt similar structures and practices in order to gain legitimacy (DiMaggio \& Powell, 1983), or ask for strategic responses - from compliance to resistance and avoidance (Oliver, 1991).

We propose that in the extreme conditions of Africa the role of institutions needs to be studied from a different perspective, helping advance theory in several ways. First, the study of firms in Africa where there is an extreme weakness in promarket institutions can help scholars identify new institutional mechanisms that are less dependent on government regulations and rules. In Africa-focused business scholarship, there has been a consensus that similar to other emerging economies, Africa can be characterized as 'suffering' from underdeveloped or missing marketsupporting institutions, a situation referred to as institutional voids (Khanna \& Palepu, 2010). Thus, both domestic and foreign firms in Africa need to 'navigate' institutional voids to survive and compete (George et al., 2016). However, since nation-level institutions that are captured in the traditional measures of the World Bank or International Monetary Fund are either absent or not applied in some African countries, studies should move from the national to the subnational level and use the context of African countries to understand variety in subnational and local norms and institutions and their effect on firm behavior.

Following the call by Phillips, Tracey and Karra (2009) to take institutional processes at multiple levels more seriously in international management research (see also Phillips \& Tracey, 2009), we encourage future studies to examine how local norms of behavior may actually 'replace' national norms. In other words, institutions are argued to differently affect firms not just because they differ in degrees of constraint, but rather because they constrain a diversity of behavior and in a diversity of ways. In such contexts, the predictions on economic relationships 
need to be on nature and variety of institutions rather than 'quality' of promarket institutions. Some of these institutions are not only informal, but rather based on different paradigms. For example, the role of faith has long received attention in studies of development (Deneulin, 2009), and scholars of religion have also highlighted the importance of notions of prosperity and capitalism in the large African Pentecostal movement (Meyer, 2007). Yet, religion has not yet been explored as an institution shaping firm behavior. More traditional relationships, like ubuntu that we discuss later, also play an important institutional role.

Second, the analysis of firms in relation to traditional communities can help identify new sources of legitimacy of firms that have been overlooked in conventional analyses of legitimation. Legitimacy is a central theme in sociologybased institutional theory. In Africa, one particularly important source and potential barrier of legitimacy is the level of community support (Bitzer \& Hamann, 2015). Communities are more than just social networks, but are often locally bounded groups of people with shared social ties, economic backgrounds, histories, religious beliefs, morals, and customs (Kepe, 1999). In the absence of effective market institutions and state regulation, and in the face of radically changing economic environments, communities play an extremely important role as rather stable infrastructures for information sharing, legitimacy building, and safeguarding contracts and loans (Bitzer \& Hamann, 2015; Holt \& Littlewood, 2015) - or of withholding those. Thus communities and community elders in many African countries are critical sources of support for new businesses and ideas, but can also be agencies of resistance and backlash (Bitzer \& Hamann, 2015). Rather than subsuming communities under the categories of social capital and networks given weak institutional frameworks, their specific importance in Africa merits a more sophisticated treatment as a distinct level of analysis. Whereas most institutional theory-inspired business research has focused on institutions at the level of state and law (North, 1990), or the level of organizational fields (DiMaggio \& Powell, 1983), theorizing of institutions and institutional processes, such as legitimacy-building, in Africa may require conceptualizing communities as its own level of institutional analysis.

Another central theme in institutional theory is institutional logics, i.e. rather stable institutional regimes, orders or organizing principles guiding actions and decision-making, including the capitalist market, the bureaucratic state, families, democracy, and religion (Friedland \& Alford, 1991). Firms are expected to operate primarily according to the logic of capitalist markets, even if varieties of capitalism produce a certain variety of orders within the capitalist framework (Hall \& Soskice, 2001). However, the African context may challenge the utility of the concept of institutional logics and call for a more extended conceptualization.

For example, partly as a consequence of ineffective formal institutions and resource constraints, many firms in Africa either operate or at least have strong ties in informal economies that operate outside of and are also denied the 
protection of formal institutions (Feige, 1990). According to the International Labor Organization (2002), over 72\% of workers in sub-Saharan Africa are employed in the informal sector. In fact, sub-Saharan Africa was the starting point for research on informal economies worldwide (Hart, 1973; Portes \& Haller, 2005), which is also why they continue to be of central concern to business researchers (George et al., 2016). The logics by which informal economy firms operate are still highly disputed. Some suggest that partly due to lack of safeguards and protection, market mechanisms are even more pronounced in the informal sector (Portes \& Haller, 2005). At the same time, research suggests that not least in Africa, informal economies are typically strongly embedded in local communities which co-determine the varieties and constraints of conducting business under informal conditions (Khavul, Bruton, \& Wood, 2009; Zoogah, Peng, \& Woldu, 2015). Studies in Africa thus promise to shed light on sources of institutional logics and on the creation of informal institutions and mechanisms for setting disputes when conducting business in informal economies.

\section{Extreme Conditions and the Resource-Based View}

The resource-based view (RBV) is a starting point for understanding how and why firms differ regarding their resource capacity, capabilities, and performance. At its core, the RBV explains firm heterogeneity by arguing that firms build up and exploit over time resources and capabilities that are not easily tradable in factor markets (Barney, 1986, 1991; Penrose, 1959; Teece, Pisano, \& Shuen, 1997). This is why their performance cannot be explained just by industry structure, the intensity of competition, or institutional constraints (Wernerfelt, 1984). Instead, firms may develop rare, rather intangible, socially complex and historically rooted capacities that may give them a longer-term competitive advantage and that may be hard to imitate (Barney, 1991). Because of this, firms are also capable of responding differently to the same institutional constraints (Oliver, 1991). They may even develop specific capabilities that allow them to not only adjust to certain political or institutional contexts, but to shape and transform the latter in their favor (Oliver \& Holzinger, 2008). In emerging economies in general (Hoskisson et al., 2000) and in African economies more specifically (George et al., 2016), relationship management and being able to build up social capital to tap into otherwise difficult to access resources can be a critical source of competitive advantage. We agree with this notion, yet we propose more radically extending the conventional scope of RBV-related approaches to adjust them to the African context.

First, one central idea in previous research based on RBV in emerging economies is that firms, on top of their productive capacities and resources, need to develop a certain strategic flexibility to compete under conditions of high political, institutional, and economic uncertainty and volatility (Wright, Filatotchev, Hoskisson, \& Peng, 2005). Firms in Africa face these challenges in 
sometimes extreme forms, forcing them to not only develop flexibility but remain in start-up mode throughout their lives, thereby improvising and adapting to changing conditions, rather than growing from an entrepreneurial firm to more differentiated and bureaucratic forms. This suggests that key assumptions around firm growth and long-term returns on investing in certain technologies, structures, and capabilities need to be revised, and with it the traditional RBV view that firms develop and refine sophisticated capabilities that serve to differentiate them. Many executives in Africa nonetheless argue that longevity affords a competitive advantage, suggesting the need for scholarship to examine whether it stems from the extent to which firms learn to continuously adjust and seek opportunities in an entrepreneurial fashion, increased legitimacy, or some other differentiator.

Second, the need to invest in location resources to substitute for inputs provided by the government also contributes to a changed conceptualization of success, with longevity and survival becoming especially important. Because firms in Africa are embedded in systems where government does not adequately provide basic infrastructure, firms are induced to expand their activities and services and substitute for the lack of inputs. For example, the extremely low levels of education prevalent in many countries limits firm profitability and leads managers to use external rather than internal capability upgrading methods to reduce this negative effect (Wang \& Cuervo-Cazurra, 2017). This changes our understanding of the bundle of resources firms develop. Many firms in Africa, not only so-called social enterprises, operate towards multiple goals simultaneously, including community benefit and profitability (Holt \& Littlewood, 2015; Kistruck \& Beamish, 2010; Rivera-Santos, Holt, Littlewood, \& Kolk, 2015).

The traditional RBV argument is that firms develop resources to enable them to compete against other firms, relying on suppliers for the provision of inputs and the government for the provision of infrastructure. In the case of firms in Africa, they have to develop not only competitive resources but also the supporting infrastructure. This changes our conceptualization of competitiveness - one of the central categories in RBV-for such firms, and what it even means for firms pursuing both social and business goals (see also below). Consider, for example, the software firm Craft Silicon in Kenya whose community-centered business model lets them recruit staff from disadvantaged communities, and allows them to move between offering business services for micro-finance firms and developing software for mobile banking apps. We know very little about how firms that pursue such community-centered business models survive in constantly changing or volatile political, institutional, and economic environments.

Third, the high levels of corruption and the personalized and unstable political systems that characterize many African countries challenge our understanding of non-market strategies and the development of resources and capabilities for managing political relationships. The traditional RBV focused on providing explanations on how firms can develop resources to compete in the marketplace. An extension developed from the study of firms in emerging economies has 
pointed out the importance of developing non-market capabilities to deal with government regulation (Ghemawat \& Khanna, 1998). A new conceptualization of non-market resources and capabilities is needed to account for the extreme instability of governments in some African countries, in which coups and countercoups are common, as well as the highly personalized nature of power, with some long-term dictators and their families controlling the country, like in Angola, Equatorial Guinea, or Zimbabwe. Relatedly, when access to government favors is scarce, a different conceptualization of political management capabilities (Oliver \& Holzinger, 2008) as a source of competitive advantage is needed.

\section{EXTENDING THEORY BY ANALYZING NEW PHENOMENA}

Going beyond theory extension and revision, the African context provides a rich array of new business-related phenomena that are largely outside the realm of established management theories. For example, several studies have pointed out that African countries are typically characterized by a high diversity of religions, ethnicities, and languages - to an extent that the validity of theories that stem from typically more homogeneous cultural and institutional contexts can be questioned. This example showcases the need to take Africa more seriously as a source of new concepts, perspectives, and potential theories of organization and international business. In other words, as Nkomo (2015) suggests, the scholarship of Africa itself needs to be decolonized. She also points out, perhaps more importantly, that a decolonial approach is per definition transdisciplinary, suggesting that Africa research could benefit from an influx of theories from other disciplines such as political science.

Prior research in emerging economy contexts has proven to be fruitful for the discovery and theorization of recent trends in an increasingly complex and integrated global economy (Cuervo-Cazurra, 2012). Such research builds on very in-depth and detailed understandings of the reality of how companies operate in such environments. For example, based on the experience of companies in India, the concept of base-of-the-pyramid strategies has been formulated, in which multinationals from advanced economies create products and services that are adapted to the needs and purchasing abilities of people at the bottom of the economic pyramid in emerging economies (Prahalad, 2005). More recently, the knowledge transfer experience of foreign companies in China and India has served as the basis for the topic of reverse innovation in which firms from advanced countries develop innovations that address the needs of poorer customers in emerging economies and bring these innovations back to advanced countries (Govindarajan \& Ramamurti, 2011). Also, much recent research on the internationalization experience of state-owned multinationals is largely based on the analysis of firms from emerging economies, not least from China (CuervoCazurra et al., 2014). 
The analysis of firms in Africa can bring many novel insights. We suggest that many trends and phenomena in Africa are more or less directly related to the continent's colonial history. Whereas prior research has already pointed out the importance of post-colonial ties in affecting foreign direct investment and market expansion (Makino \& Tsang, 2011; Rangan \& Drummond, 2004), we discuss several other aspects of business conduct that demonstrate how postcolonial trajectories have penetrated business conduct and organizational life in Africa. More specifically we discuss: (1) the meaning of home country, (2) the influence of diaspora networks, (3) assumptions behind cultural and institutional distance, and (4) new organizational forms.

\section{Migrating Multinationals and Home Country Conceptualization}

Africa research may contribute to a richer understanding of what the home country of a company means. There is a large literature in international marketing identifying the country of origin of firms as a source of advantage or disadvantage of exported products (Bilkey \& Nes, 1982; Peterson \& Jolibert, 1995). It finds that firms from emerging markets tend to have their products discriminated against by consumers because of the association with the lower level of development of the country. A different and more subtle focus is the home country of the firm and how this plays a role in not only the export of products, but also in the perception of the whole firm in its international expansion. The deep discrimination that firms in Africa suffer, with the perception in many business circles that they are not up to par with other global competitors, has induced many of them to actively seek a dissociation with the home country by moving their headquarters outside Africa and becoming migrating multinationals (Barnard, 2014). For example, South African multinationals have moved headquarters outside Africa, usually to the UK, thereby exploiting post-colonial ties. This helped them reduce negative perceptions of the country on the companies, previously as a way to bypass sanctions, as well as to access deeper capital markets.

These migrating multinationals challenge our understanding of the association of a company to one home country and the usual identification of the home country of a firm with the country in which the firm was initially founded. In the case of some South African multinationals, it is not fully clear whether one can identify these companies as being South African (Barnard, 2014). Analyses of internationalization processes and the notion of distance between headquarters and subsidiaries (Johanson \& Vahlne, 1977) must be rethought. Arguments, measurements and implications change depending on whether one considers headquarters to be based on the country of creation, on the country of incorporation, or on the country where the managers live. Hence, the study of firms in Africa opens the possibility of being much more nuanced and sophisticated about the notions of home. 


\section{Diaspora Networks within and across Countries}

Another empirical domain in which the analysis of firms in Africa can shed new light is the study of international diaspora networks, in which businesses are built and expanded via the social relationships provided by individuals coming from the same ethnic group. Business research on the role of diaspora networks gained recent importance in the context of India (Bresnahan, Gambardella, \& Saxenian, 2001; Kenney, Breznitz, \& Murphree, 2013; Saxenian, 2005) and has a longer tradition from the analysis of networks among Jewish merchants in medieval Europe. These networks are built on the basis of trust between individuals from the same ethnic group located in different countries and serve to facilitate crossborder relationships and business deals.

The African context offers an even richer display of diaspora relationships and multi-ethnic ties across the continent itself. For example, diaspora relations include the relationships among ethnic groups of traders that settled in Africa and maintained international relationships, such as Arab and Indian traders. Those ties continue to affect contemporary entrepreneurship. New aspects of the traditional colonial relationships between former colonial powers and colonies also open the possibility for a reconceptualization of diaspora relationships. Thus, for example, in some African countries, the descendants of the former colonial power have been actively discriminated against by the government, as in the case of Zimbabwe. Such behavior is in contrast to the experience of other regions like Latin America where the descendants of colonialists are at the cusp of both economic and political power. This challenges the typical understanding of the former colonizer and colony derived from studies of other regions.

But diasporas also include the more recent wave of Chinese migrants that offer a new understanding of the functioning of diaspora as many of these traders have moved to Africa following the move of Chinese multinationals who have won large infrastructure contracts. As the Chinese multinationals brought with them the necessary labor, Chinese entrepreneurs followed the multinationals abroad to provide services to the expatriates.

There are also types of diaspora that challenge the usual ethnic connection, for example between African countries and ex-Eastern bloc countries in Europe, such as between Mozambique, Namibia, and former East Germany, where many Africans received training, during the battles for independence. In such cases, there are no ethnic relationships but instead educational relationships that have facilitated international commerce. This creates the possibility for studies on educational relationships that have been mostly absent from the business literature.

Additionally, although much of the research around business and diasporas is quite optimistic about the stimulating effect of returnees, in the case of studies in Africa there is emerging evidence of a 'returnee liability' (Obukhova, 2012). Evidence from Ghana (Mayer, Harima, \& Freiling, 2015) suggests that returnees and diasporans seem incapable of effectively brokering between their home 
country and country of residence, with both relying primarily on networks in the country where they are resident. Barnard and Pendock (2013) show that the willingness to share knowledge of South African diasporans is strongly shaped by how they feel about both their home and host country. Again, Africa research promises to add nuance to our understanding of diaspora effects.

\section{Recasting Gultural and Institutional Distance}

Africa research may also force us to question assumptions behind concepts of cultural and institutional distance. Traditional international business literature tends to view the country as the primary unit of analysis as it encompasses a society that over the course of history has defined the geographical boundaries and established a sense of national unity. However, African countries tend to have high levels of domestic cultural diversity (Luiz, 2015). Traditionally, African societies were typically tribal. Colonizers drew national borders rather artificially, thereby imposing a new institutional order that would later turn into nation states. However, these national boundaries did not take into account the reality of the traditional tribal and religious identities, which promote cultural richness, but also lead to continuous latent conflicts and tensions.

Given the difficulty and lack of state capacity in imposing borders, as well as the nomadic tradition of some ethnic groups, the analysis of institutional and cultural distance changes. Whereas studies of other regions have identified the movement of immigrants and colonists across borders as a way to reduce the distance between countries, the causality reverses in the case of some African countries Ethnic groups were already in place and national borders were superimposed on those groups establishing artificial divisions and migrations. Thus, a deeper understanding of historical events can add a better understanding of what we mean by cultural and institutional distance and challenge our conceptualization of the country as the primary unit of analysis. Given that many African countries became nation states within living memory, with the decolonization of the 1960s, and continued until recently with the split of Sudan into two countries in 2011, Africa is a particularly appropriate setting for this type of endeavor.

Another challenge to the notion of the state as the primary unit of analysis in the study of distances is the existence of a variety of ethnic groups, multiple languages, and cultural identities within particular nation-states in Africa. Whereas other multicultural countries have aimed at building a sense of national unity by highlighting the difference with other countries, for example India versus Pakistan, such differences with the neighbor are less clear in the case of many African countries. The neighbor was often an artificial creation and there could be larger differences with other groups and tribes within the country than with neighboring countries, to the point of resulting not only in animosity, but even wars. This raises issues around the validity of concepts such as national culture (Hofstede, 1980), and it calls for revising how culture and related concepts are understood. 


\section{New Hybrid Organizational Forms}

The specific post-colonial conditions in Africa have arguably also produced specific organizational forms. We already argued that due to high institutional and economic uncertainty, many firms in Africa will remain in an entrepreneurial state that may rely more on individual skills and aspirations of entrepreneurs and managers than on organizational structures and capabilities. It is unclear whether firms in Africa can be sufficiently described by established terminology or whether they are manifestations of new types of entrepreneurial or temporary organizational forms. Moreover, given the strong rootedness of many firms in local communities, new hybrid forms may have developed that specialize in developing products and services that serve collective social or ecological needs, while also benefiting paying customers individually, i.e., what Porter and Kramer (2011) have called creating shared value. One example is WaterHealthInternational, a forprofit organization that has developed innovative water purification techniques to distribute clean water at low costs to more than a million people around the world, including in Ghana (Porter \& Kramer, 2011). This organization illustrates the so-called hybrid organization, i.e. an "organization that possess [es] "significant" characteristics of more than one sector (public, private and third)' (Billis, 2010: 3). Hybrid organizations are capable of creating shared value by combining commercial with social goals and by following multiple institutional logics, i.e. commercial and social, simultaneously (Battilana \& Dorado, 2010; Battilana \& Lee, 2014; Jay, 2013; Porter \& Kramer, 2011).

While hybrid organizations have become increasingly important in various contexts, as they help address social issues when state and philanthropic approaches are limited in their ability to do so (Kickul \& Lyons, 2012), in the African context, in particular so-called 'community-based hybrids' are on the rise. They have been defined as hybrid organizations that serve local communities but also make extensive use of community resources to serve regional or global markets with their products and services (Holt \& Littlewood, 2015; Manning, Kannothra, \& Wissman-Weber, 2017). Examples of this are so-called impact sourcing service providers (ISSPs), such as Craft Silicon and Digital Divide Data, that operate out of African countries and that specialize in hiring and training of staff from disadvantaged groups in society for global business services (IAOP, 2014; Rockefeller Foundation, 2013). In sub-Saharan Africa, ISSPs enjoy a competitive advantage over regular outsourcing firms as they better utilize community resources, along with a sophisticated infrastructure of community support organizations, to access talent better while promoting more inclusive employment and development (Manning et al., 2017).

It will be critical for future research to understand better how and under what conditions such community-based hybrid models can be implemented effectively, and what challenges such organizational forms face. For example, such forms may allow - but also force - firms to align their growth and diversification strategies 
with community needs rather than just firm resources or market opportunities in the traditional sense (Kannothra, Manning, \& Haigh, 2017). While a firm like the software producer Craft Silicon in Kenya requires different skills to target different customers for its different offerings, both its staffing strategy and its product lines may exploit the same community ties for marketing, branding and implementation (see also Manning et al., 2017). This brings both unique synergistic opportunities while also posing significant challenges.

\section{BUILDING NEW THEORIES BASED ON ALTERNATIVE PARADIGMS OF SOGIAL RELATIONSHIPS}

A third way in which research on firms in Africa can contribute to business scholarship is by offering new theoretical paradigms that re-conceptualize social relations based on the traditions and philosophies of African countries. These traditions differ markedly from the ones that underpin current conceptualizations of firms, which were built on the experience of firms from advanced Western economies. Hence, business research in Africa may serve as an alternative foundation for (Western) organization theories and theories of the firm - similar to inspirations from other world regions.

In the 1980s and 1990s, management philosophies from Japan, such as kaizen or theory Z (Ouchi, 1981), had a significant influence on Western management theory, for example by inspiring the development of the knowledge-based view of the firm and innovation scholarship (Nonaka \& Takeuchi, 1995). More recent research in China has produced a promising stream of research focusing on mechanisms of guanxi (Luo, Huang, \& Wang, 2012), yin/yang (Fang, 2012) and the teachings of Confucius (Shapiro \& Li, 2016), which have aimed to challenge established theories of networks, trust-building, and change (Chen, Chen, \& Huang, 2013; Park \& Luo, 2001; Xin \& Pearce, 1996). Such paradigms may help counter-act the often-criticized imperialist tendencies of Anglo-Saxon management research and education (Amdam, 1996).

One example of how Africa's history may challenge established thinking is the notion of humanizing leadership. In the Western-based management literature, from McGregor's (1960) Theory X and Y to the recent work of Petriglieri and Petriglieri (2015), humanizing leadership is about countering Taylorist approaches where humans are at risk of being reduced to machines. However, dehumanization can happen in multiple ways, and people can be denied their humanity by being diminished as either machines or animals (Haslam, 2006). In Africa, with its still relatively recent history of colonialism and even slavery, people were presumed by colonial powers to be animal-like and spoken of as chattel, savages, or primitives. Contemporary business in Africa takes place in a context where people are mindful of this history.

Thus, scholarship in Africa may challenge established paradigms in management in even more fundamental ways. In particular, we focus next 
on indigenous philosophies that may help re-frame business conduct in Africa and inspire new theorizing, by looking at the importance of relationships and communities in new ways. Specifically, we briefly introduce two Africa-based philosophies - ubuntu and kgotla - that may inspire a paradigm shift to guide future empirical research and theorizing of business conduct within and beyond Africa.

\section{Toward Humanizing Relationships: Ubuntu}

One of the schools of thought originating in Africa is ubuntu, a philosophy from Southern Africa that provides a humanistic view of the individual in the sense that 'a person is a person through other people.' Ubuntu focuses on 'humanness, a pervasive spirit of caring and community, harmony and hospitality, respect and responsiveness that individuals and groups display for one another' (Mangaliso, 2001: 24). This contrasts with most of the theories of the firm that have been developed in the West and rely on an implicit individualistic view. Within a profoundly different context to explain why we have firms, one may want to understand the social dimension of companies and view these as a mechanism that exists to help people rather than to maximize profit.

The recent work on social entrepreneurship in Africa (Manning et al., 2017; Rivera-Santos et al., 2015) confirms the importance of this social dimension. Moreover, fieldwork in South Africa has uncovered several diverse types of organizations characterised "social enterprises" beyond the more narrow definition of enterprises combining beyond conventional "social enterprises" that are typically defined as enterprises combining social and profitability objectives (Battilana \& Lee, 2014). For example, a collective, composed of five women, who sells snacks and does catering with a profit motive, but baulks at earning more than what is needed to meet its members fluctuating financial needs, challenges established categories. Such enterprises are influenced by the ubuntu philosophy. Some research on the implications of ubuntu has already been done (Mangaliso, 2001; Mbigi \& Maree, 1995), and more work can help develop an alternative explanation of why companies exist and how companies compete and succeed.

Although ubuntu is specific to Southern Africa, scholars of Tanzania and Malawi have uncovered a similar humanistic orientation in organizations. In theorizing organizational change, scholars found the importance of social achievement, social identity, and social need to counterbalance the organizational requisites (AfroCentric Alliance, 2001). Further analyzing how more and less formal as well as social enterprises operate and succeed under this tradition would require understanding how firms are primarily seen as mechanisms that facilitate the establishment of relationships with others. This would imply that their sources of legitimacy and purpose stem in no small part from their ability to connect people and their ability to make people feel related. 


\section{Toward a Community-Based Theory of the Firm: Kgotla}

The kgotla is a forum where Botswanan men (historically) would meet to discuss issues of shared interest. Traditionally, kgotla has been a participatory process at the village or community level that emphasizes consultation, mediation, consensus building, and harmony (Beugre, 2016). It was famously the mechanism through which the paramount chief and later Prime Minister Seretse Khama engaged with the Batswana when he sought approval for his marriage to the British woman Ruth Williams.

Although it is in some sense comparable to mechanisms of consensus-building in other institutional contexts, such as works councils in Germany, very little scholarly work has been done on the kgotla. Moholo (2015) describes it as 'the art of leadership through dialogue' (91). Similar to the ubuntu philosophy, kgotla emphasizes the common good and the welfare of the community, rather than individual goals.

In contemporary Botswana, the use of kgotla as a mechanism for participative management is widespread (Beugré, 2015). Recent fieldwork done by researchers from the Gordon Institute of Business Science has found that even subsidiaries of foreign multinationals find that they are expected to conduct kgotla to get decisions made. Understanding not only how kgotla functions, but also how a small and relatively poor African country was able to insist that foreign multinationals acknowledge and implement one of its historical governance structures, are important avenues for future research.

Both ubuntu and kgotla point to the importance of communities and tribal structures in both enabling and conditioning business conduct in Africa. A focus on relational structures as control and governance mechanisms in opposition to markets and hierarchies is not new in management studies. For example, Ouchi (1980) conceptualized clans as alternative control mechanisms guiding economic exchanges based on traditions (rather than rules or prices), supported by a combination of reciprocity, legitimate authority, and common values and beliefs. Powell (1990), in a similar fashion, introduced networks as organizational forms in opposition to markets and hierarchies, by specifying them as trust and reciprocitybased relational structures that allow for economic exchanges both markets and hierarchies are ill-suited for.

But research on Africa with its renewed focus on relationships may require of scholars to revisit those older attempts at theorizing. Our brief review suggests that tribal or community structures in Africa share some of the properties of clans and networks as conceptualized previously, but also feature new properties. For example, given the lack of formal market institutions as well as employment opportunities in large hierarchies, operating in or through community structures seems more a necessity rather than an option in African countries. It is therefore necessary to better understand how community structures facilitate and constrain various forms of economic exchange - from simple to complex, from predictable to uncertain. 
Table 4. Using context to build theory: Three alternative approaches

\begin{tabular}{|c|c|c|c|}
\hline & $\begin{array}{c}\text { Theorizing from extreme } \\
\text { conditions }\end{array}$ & $\begin{array}{c}\text { Theorizing from new } \\
\text { phenomena }\end{array}$ & $\begin{array}{c}\text { Theorizing from alternative } \\
\text { paradigms of social } \\
\text { relationships }\end{array}$ \\
\hline $\begin{array}{l}\text { Mechanism for } \\
\text { expanding theory }\end{array}$ & $\begin{array}{l}\text { Identify and test implicit } \\
\text { assumptions } \\
\text { embodied in existing } \\
\text { theories the presence } \\
\text { of extreme conditions }\end{array}$ & $\begin{array}{l}\text { Identify hitherto } \\
\text { undocumented } \\
\text { phenomena and } \\
\text { theorize their } \\
\text { functioning }\end{array}$ & $\begin{array}{l}\text { Apply different } \\
\text { philosophical } \\
\text { approaches to } \\
\text { business and } \\
\text { organizing to } \\
\text { develop novel theory }\end{array}$ \\
\hline $\begin{array}{l}\text { Triggers for } \\
\text { phenomenon }\end{array}$ & $\begin{array}{l}\text { Underdeveloped } \\
\text { infrastructure and } \\
\text { institutions }\end{array}$ & $\begin{array}{l}\text { Ways of doing } \\
\text { business that } \\
\text { respond to local } \\
\text { needs }\end{array}$ & $\begin{array}{l}\text { Different conceptions } \\
\text { of social relationships }\end{array}$ \\
\hline Examples & $\begin{array}{l}\text { Expanded use of } \\
\text { institutional theory } \\
\text { beyond its typical } \\
\text { focus on formal } \\
\text { institutions }\end{array}$ & $\begin{array}{l}\text { Refined } \\
\text { understanding of } \\
\text { the possibilities and } \\
\text { limitations of } \\
\text { diaspora networks }\end{array}$ & $\begin{array}{l}\text { New community-based } \\
\text { theories (e.g., kgotla) } \\
\text { that challenge the } \\
\text { individualistic } \\
\text { assumption of } \\
\text { traditional } \\
\text { management } \\
\text { theories }\end{array}$ \\
\hline
\end{tabular}

In sum, studying locally embedded communities and value systems helps better understand the limits of Western models in stimulating business and economic growth in various other contexts in the world. For example, Bagire and Namada (2015) argue that the focus of Western (business) education on corporate goals is at odds with the traditional focus of education in many African communities on personal growth, integrity, and community service. In other words, local values often collide with imported values. It will be thus critical to understand how the co-existence of, and partial conflict between such value systems affect business education and practice.

\section{GONGLUSION}

In this article, we argued and explained how research on firms in Africa can serve as a laboratory for extending our current understanding of theories of organization. We proposed that Africa and its businesses are not only an interesting setting that has received relatively little attention in the management literature but also, and more importantly, a setting that can help existing literature in three ways, which Table 4 summarizes: extreme conditions, new phenomena, and alternative paradigms of social relationships.

First, some of the conditions of the environment in which firms operate are quite extreme, particularly regarding the underdevelopment of infrastructure and institutions. These conditions can help identify some of the implicit assumptions upon which current theories of the organization and their decision-making are built, and thus extend those theories by modifying their predictions to address business under extreme conditions. 
A second approach is to delve into the analysis of these firms and their context to identify phenomena that are new and that can be the basis for new areas of research. These require going beyond the usual approach of trying to fit theories to existing phenomena and, instead, analyzing the phenomena to try to identify new mechanisms and factors that influence how organizations operate under new conditions.

A third and more complex approach is to go even deeper in the understanding of the context in Africa and build new theories of the organization by understanding paradigms that are alternative to the philosophical approaches that dominate Western thinking and the theories of the organization built on such approaches. Instead of the traditional individualistic approach that underpins much of existing theories of the organization, management scholars can analyze in detail philosophies such as Ubuntu and create new approaches to our understanding of organizations and their place in society.

This three-pronged approach to building theory is also a useful guide for experts from other regions, who seek to identify how the conditions of operation there can serve as the basis for improving our contextual understanding of management. However, while we are keen on learning from Africa and optimistic about the continent's prospects, we want to emphasize that scholars who focus on Africa can also advance business research by not glossing over dysfunctionality when it occurs. For example, Luiz and Stewart (2014) find that South African multinationals investing in the wider Africa often see themselves as victims of an institutionally underdeveloped context, and are blind to their role in strengthening a culture of corruption. They suggest that businesses are not simply 'takers' of an institutional environment, but also 'makers'; that they participate in a dynamic process that can either perpetuate or mitigate a culture of corruption.

Nonetheless, by invoking new paradigms of management, Africa-based research can play an important role. It can do so not only by providing alternatives to Anglo-Saxon business education, similar to what research in Japan and China has achieved in the past, but also by resisting the ongoing legacy of former colonial powers in higher education in Africa (Bagire \& Namada, 2015). We, therefore, hope that the suggestions presented here are useful not only for encouraging more studies of firms in Africa but also for encouraging more studies that take Africa and its businesses seriously as the basis for extending management theory.

\section{NOTE}

Authors appear in alphabetical order. We thank Arie Y. Lewin for providing useful suggestions for improvement. Alvaro Cuervo-Cazurra thanks the Lloyd Mullin fellowship for financial support.

\section{REFERENGES}

ADBG. 2015. African Economic Outlook 2015. Statistics. African Development Bank Group. [Cited 4 November 2016]. Available from URL: http://www.africaneconomicoutlook.org/en/ statistics/ 
Africa Report. 2015. Top 500 Companies in Africa 2015. [Cited 4 November 2016]. Available from URL: http://www.theafricareport.com/Top-500-Companies/ top-500-companies-in-africa-2015.html

Africa Telecoms News. 2015. African Telecoms News by Country. [Cited 4 November 2016]. Available from URL: http://www.africantelecomsnews.com/News/Africa_news_by_country.html

Afro-Centric Alliance. 2001. Indigenising organizational change: Localization in Tanzania and Malawi.Journal of Managerial Psychology, 16(1): 59-78.

Amdam, R. P. 1996. Management, education and competitiveness. Europe, Japan and the United States. New York: Routledge.

Bagire, V., \& Namada, J. 2015. Management theory, research and practice for sustainable development in Africa: A commentary from a practitioner's perspective. Africa Journal of Management, 1(1): 99-108.

Barasa, L., Knoben, J., Vermeulen, P., Kimuyu, P., \& Kinyanjui, B. 2017. Institutions, resources and innovation in East Africa: A firm level approach. Research Policy, 46(1): 280-291.

Barnard, H. 2014. Migrating EMNCs and the theory of the multinational. In A. Cuervo-Cazurra \& R. Ramamurti (Eds.), Understanding multinationals from emerging markets: 195223. New York: Cambridge University Press.

Barnard, H., \& Pendock, C. 2013. To share or not to share: The role of affect in knowledge sharing by individuals in a diaspora. Journal of International Management, 19(1): 47-65.

Barney, J. 1986. Strategic factor markets: Expectations, luck, and business strategy. Management Science, 32(10): 1231-1241.

Barney, J. 1991. Firm resources and sustained competitive advantage. Journal of Management, 17(1): 99-120.

Battilana, J., \& Dorado, S. 2010. Building sustainable hybrid organizations: The case of commercial microfinance organizations. Academy of Management Journal, 53(6): 1419-1440.

Battilana, J., \& Lee, M. 2014. Advancing research on hybrid organizing - Insights from the study of social enterprises. The Academy of Management Annals, 8(1): 397-441.

Beugré, C. D. 2016. The challenge of management scholarship in Africa. Africa Journal of Management, 1(1): 94-98.

Bilkey, W.J., \& Nes, E. 1982. Country-of-origin effects on product evaluations. Journal of International Business Studies, 13(1): 89-99.

Billis, D. 2010. Hybrid organizations and the third sector: Challenges for practice, theory and policy. New York: Palgrave Macmillan.

Bitzer, V., \& Hamann, R. 2015. The business of social and environmental innovation. In V. Bitzer, R. Hamann, M. Hall, \& E. W. Griffin-EL (Eds.), The business of social and environmental innovation: 3-24. New York: Springer International Publishing.

Bresnahan, T., Gambardella, A., \& Saxenian, A. 2001. 'Old economy' inputs for 'new economy' outcomes: Cluster formation in the new Silicon Valleys. Industrial and Corporate Change, 10(4): 835-860.

Chen, C. C., Chen, X. P., \& Huang, S. 2013. Chinese guanxi: An integrative review and new directions for future research. Management and Organization Revieze, 9(1): 167207.

Crawford, G., \& Lynch, G. 2013. Democratization in Africa: Challenges and prospects. New York: Routledge.

Cuervo-Cazurra, A. 2012. Extending theory by analyzing developing country multinational companies: Solving the Goldilocks debate. Global Strategy Journal, 2(3): 153-167.

Cuervo-Cazurra, A., Inkpen, A., Musacchio, A., \& Ramaswamy, K. 2014. Governments as owners: State-owned multinational companies. Journal of International Business Studies, 45(8): 919-942.

Deneulin, S. 2009. Religion in development: Rezriting the secular script. London: Zed Books Ltd.

DiMaggio, P., \& Powell, W. W. 1983. The iron cage revisited: Institutional isomorphism and collective rationality in organizational fields. American Sociological Revieze, 48(2): 147-160.

Economist. 2013. Africa rising: A hopeful continent. [Cited 13 September 2016]. Available from URL: http://www.economist.com/news/special-report/21572377-africanlives-have-already-greatly-improved-over-past-decade-says-oliver-august

Fang, T. 2012. Yin Yang: A new perspective on culture. Management and Organization Revieze, 8(1): 25-50. 
Feige, E. L. 1990. Defining and estimating underground and informal economies: The new institutional economics approach. World Development, 18(7): 989-1002.

Forbes. 2016. The zorld's biggest public companies. [Cited 4 November 2016]. Available from URL: http://www.forbes.com/global2000/list/44/\#tab:overall

Friedland, R., \& Alford, R. R. 1991. Bringing society back in: Symbols, practices and institutional contradictions. In W. W. Powell \& P. J. DiMaggio (Eds.), The neze institutionalism in organizational analysis: 232-263. Chicago: The University of Chicago Press.

George, G., Corbishley, C., Khayesi, J. N. O., Haas, M. R., \& Tihanyi, L. 2016. Bringing Africa in: Promising directions for management research. Academy of Management Journal, 59(2): 377-393.

Ghemawat, P., \& Khanna, T. 1998. The nature of diversified business groups: A research design and two case studies. Journal of Industrial Economics, 46(1): 35-62.

Govindarajan, V., \& Ramamurti, R. 2011 . Reverse innovation, emerging markets, and global strategy. Global Strategy Journal, 1(3-4): 191-205.

Hall, P. A., \& Soskice, D. W. 2001. Varieties of capitalism: The institutional foundations of comparative advantage. Oxford: Oxford University Press.

Hart, K. 1973. Informal income opportunities and urban employment in Ghana. Journal of Modern African Studies, 11(1): 61-89.

Haslam, N. 2006. Dehumanization: An integrative review. Personality and Social Psychology Revieze, 10(3): 252-264.

Henderson, J. V., Storeygard, A., \& Roberts, M. 2013. Is urbanization in Sub-Saharan Africa different? World Bank policy research working paper \# 6481. Washington, D. G: World Bank.

Hofstede, G. 1980. Culture and organizations. International Studies of Management \& Organization, 10(4): 15-41.

Holt, D., \& Littlewood, D. 2015. Identifying, mapping, and monitoring the impact of hybrid firms. California Management Revieze, 57(3): 107-125.

Hoskisson, R. E., Eden, L., Lau, C. M., \& Wright, M. 2000. Strategy in emerging economies. Academy of Management Journal, 43(3): 249-267.

IAOP. 2014. Impact sourcing 101: Innovative outsourcing with positive business and social impact. International Association of Outsourcing Professionals. [Cited 10 October 2016]. Available from URL: https: //www.rockefellerfoundation.org/report/impact-sourcing-101/

International Labor Organization. 2002. Women and men in the informal economy: A statistical picture. Geneva. Switzerland.

Jay, J. 2013. Navigating paradox as a mechanism of change and innovation in hybrid organizations. Academy of Management Journal, 56(1): 137-159.

Johanson, J., \& Vahlne, J.-E. 1977. The internationalization process of the firm-A model of knowledge development and increasing foreign market commitments. Journal of International Business Studies, 8(1): 23-32.

Kannothra, C. G., Manning, S., \& Haigh, N. 2017. How hybrids manage growth and socialbusiness tensions in global supply chains: The case of impact sourcing. Fournal of Business Ethics, Forthcoming.

Kenney, M., Breznitz, D., \& Murphree, M. 2013. Coming back home after the sun rises: Returnee entrepreneurs and growth of high tech industries. Research Policy, 42(2): 391-407.

Kepe, T. 1999. The problem of defining 'community': Challenges for the land reform programme in rural South Africa. Development Southern Africa, 16(3): 415-433.

Khanna, T., \& Palepu, K. 2010. Winning in emerging markets: A road map for strategy and execution. Boston: Harvard Business Press.

Khavul, S., Bruton, G. D., \& Wood, E. 2009. Informal family business in Africa. Entrepreneurship Theory and Practice, 33(6): 1219-1238.

Kickul, J., \& Lyons, T. 2012. Understanding social entrepreneurship: The relentless pursuit of mission in an ever changing world. New York: Routledge.

Kistruck, G. M., \& Beamish, P. W. 2010. The interplay of form, structure, and embeddedness in social intrapreneurship. Entrepreneurship Theory \& Practice, 34(4): 735-761.

Kolk, A., \& Rivera-Santos, M. 2016. The state of research on Africa in business and management insights from a systematic review of key international journals. Business E Society, in press.

Little, K. 2013. Urbanization as a social process: An essay on movement and change in contemporary Africa. London: Routledge. 
Luiz, J. M. 2015. The impact of ethno-linguistic fractionalization on cultural measures: Dynamics, endogeneity and modernization. Journal of International Business Studies, 46(9): 10801098.

Luiz, J. M., \& Stewart, C. 2014. Corruption, South African multinational enterprises and institutions in Africa.Journal of Business Ethics, 124(3): 383-398.

Luo, Y., Huang, Y., \& Wang, S. L. 2012. Guanxi and organizational performance: A meta-analysis. Management and Organization Revieze, 8(1): 139-172.

Makino, S., \& Tsang, E. W. 2011 . Historical ties and foreign direct investment: An exploratory study. Journal of International Business Studies, 42(4): 545-557.

Mangaliso, M. P. 2001. Building competitive advantage from ubuntu: Management lessons from South Africa. Academy of Management Executive, 15(3): 23-33.

Manning, S., Kannothra, C. G., \& Wissman-Weber, N. 2017. The strategic potential of communitybased hybrid models: The case of global business services in Africa. Global Strategy Journal, 7: $125-149$.

Mayer, S. D., Harima, A., \& Freiling, J. 2015. Network benefits for Ghanaian diaspora and returnee entrepreneurs. Entrepreneurial Business and Economics Revieze, 3(3): 95-122.

Mbigi, L., \& Maree, J. 1995. Ubuntu, the spirit of African transformation management. Randburg, South Africa: Knowledge Resources.

McGregor, D. 1960. Theory X and theory Y. Organization theory, 358-374.

Meyer, B. 2007. Pentecostalism and neo-liberal capitalism: Faith, prosperity and vision in African Pentecostal-Charismatic churches. Journal for the Study of Religion, 20(2): 5-28.

Moholo, L. K. 2015. Africa Academy of Management 2nd Biennial Conference at the University of Botswana, Gaborone 'Sustainable Development in Africa through Management Theory, Research and Practice' Official Opening. Africa Journal of Management, 1(1): 89-93.

Nkomo, S. M. 2011. A postcolonial and anti-colonial reading of 'African' leadership and management in organization studies: Tensions, contradictions and possibilities. Organization, 18(3): 365-386.

Nkomo, S. M. 2015. Challenges for management and business education in a 'developmental' state: The case of South Africa. Academy of Management Learning \& Education, 14(2): 242258.

Nonaka, I., \& Takeuchi, H. 1995. The knowledge-creating company. New York: Oxford University Press.

North, D. 1990. Institutions, institutional change and economic performance. Cambridge: Cambridge University Press.

Obukhova, E. 2012. Why not all sea-turtles become brokers: The conflict between category membership and brokerage among returnee-firms in China. MIT Sloan Research Paper No. 4899-11.

Oliver, C. 1991. Strategic responses to institutional constraints. Academy of Management Review, 16(1): 145-179.

Oliver, C., \& Holzinger, I. 2008. The effectiveness of strategic political management: A dynamic capabilities framework. Academy of Management Revieze, 33(2): 496-520.

Ouchi, W. G. 1980. Markets, bureaucracies, and clans. Administrative Science Quarterly, 25(1): 129-141.

Ouchi, W. G. 1981. Theory Z. New York: Avon Books.

Park, S. H., \& Luo, Y. 2001. Guanxi and organizational dynamics: Organizational networking in Chinese firms. Strategic Management Journal, 22(5): 455-477.

Peng, M., Sun, S. L., Pinkham, B., \& Chen, B. 2009. The institution based view as a third leg for a strategy tripod. Academy of Management Perspectives, 23(3): 63-81.

Penrose, E. 1959. The theory of the growth of the firm. New York: John Wiley and Sons.

Peterson, R. A., \& Jolibert, A. J. P. 1995. A meta-analysis of country-of-origin effects. Journal of International Business Studies, 26(4): 883-900.

Petriglieri, G., \& Petriglieri, J. L. 2015. Can business schools humanize leadership? Academy of Management Learning \& Education, 14(4): 625-647.

Phillips, N., \& Tracey, P. 2009. Institutional theory and the MNG. Academy of Management Revieze, 34(1): 169-171.

Phillips, N., Tracey, P., \& Karra, N. 2009. Rethinking institutional distance: Strengthening the tie between new institutional theory and international management. Strategic Organization, 7(3): 339-348. 
Porter, M. E., \& Kramer, M. R. 2011. Creating shared value. Harvard Business Revieze, 89(1/2): $62-77$.

Portes, A., \& Haller, W. 2005. The informal economy. In N. Smelser \& R. Swedberg (Eds.), Handbook of economic sociology (2nd ed.). Princeton, NJ: Princeton University Press.

Powell, W. W. 1990. Neither market nor hierarchy: Network forms of organization. Research in Organizational Behavior, 12: 295-336.

Prahalad, C. K. 2005. The fortune at the bottom of the pyramid: Eradicating poverty through profits. Philadelphia: Wharton Business School Press.

Rangan, S., \& Drummond, A. 2004. Explaining outcomes in competition among foreign multinationals in a focal host market. Strategic Management Journal, 25(3): 285-293.

Rivera-Santos, M., Holt, D., Littlewood, D., \& Kolk, A. 2015. Social entrepreneurship in subSaharan Africa. Academy of Management Perspectives, 29(1): 72-91.

Rockefeller Foundation. 2013. Digital jobs in Africa: Catalyzing inclusive opportunities for youth. Retrieved from Rockefeller Foundation. Available from URL: https://assets.rockefellerfoundation.org/ app/uploads/20131217164951/Catalyzing-Inclusive-Opportunities-For-Youth.pdf

Saxenian, A. 2005. From brain drain to brain circulation: Transnational communities and regional upgrading in India and China. Studies in Comparative International Development, 40(2): $35-61$.

SeedCo. 2016. 2016 Annual Report. [Cited 19 February 2017]. Available from URL: http:// b2icontent.irpass.cc/2050/167603.pdf?AWSAccessKeyId=1Y51NDPSZK99KT3F8VG2\& Expires $=1487810049 \&$ Signature $=$ APwmas0wyuWsEkNHvAT6o2V3VbM\%3D

Shapiro, D., \& Li, J. 2016. Understanding the 'enigma' of Chinese firm performance: Confucius and beyond. Management and Organization Revieze, 12(2): 259-267.

Teece, D. J., Pisano, G., \& Shuen, A. 1997. Dynamic capabilities and strategic management. Strategic Management Journal, 18(7): 509-533.

Turok, I., \& McGranahan, G., 2013. Urbanization and economic growth: The arguments and evidence for Africa and Asia. Environment and Urbanization, 25(2): 465-482.

Wang, S., \& Cuervo-Cazurra, A. 2017. Overcoming human capital voids in underdeveloped countries. Global Strategy Journal, 7(1): 36-57.

Wernerfelt, B. 1984. A resource-based view of the firm. Strategic Management Journal, 5(2): 171-180.

Willems, F. 2010. Democratic Republic of Congo: Lubumbashi to Kinshasa. Expedition Portal, 19 October 2010. [Cited 13 December 2016]. Available from URL: http://www.expeditionportal.com/ forum/threads/50799-Democratic-Republic-of-Congo-Lubumbashi-to-Kinshasa

Wright, M., Filatotchev, I., Hoskisson, R. E., \& Peng, M. W. 2005. Guest editors' introduction: Strategy research in emerging economies: Challenging the conventional wisdom. Journal of Management Studies, 42(1): 1-33.

Xin, K. K., \& Pearce, J. L. 1996. Guanxi: Connections as substitutes for formal institutional support. Academy of Management Journal, 39(6): 1641-1658.

$\mathrm{Xu}, \mathrm{D} .$, \& Meyer, K. E. 2012. Linking theory and context: 'Strategy research in emerging economies' after Wright et al. (2005).Journal of Management Studies, 50(7): 1322-1346.

Zoogah, D. B., Peng, M. W., \& Woldu, H. 2015. Institutions, resources, and organizational effectiveness in Africa. The Academy of Management Perspectives, 29(1): 7-31. 